\title{
WRITING (TEXT CREATION) DEVELOPMENT OF PRIMARY STUDENTS AT THEIR MOTHER TONGUE LESSONS: TEACHERS' ATTITUDE
}

\author{
Nijolè Bražienè \\ Šiauliai University, Lithuania \\ Daiva Grakauskaitè-Karkockienè \\ Vytautas Magnus University, Lithuania
}

\begin{abstract}
Referring to the results of the quantitative research, the article deals with how the primary teachers of the town $\mathrm{X}$ of Lithuania establish conditions for the formation of students' text creation skills; how text creation activities are organized at their mother tongue lessons; what teachers' attitude towards students' abilities to perform creative text tasks is. Referring to the data of the research, primary teachers working according to the curriculum of mother tongue education do not have enough time for the formation of students' text creation skills; only slightly more than a half of the teachers at least once a week give a lesson to form students' creative text skills and prepare students to create a text - they give a whole lesson on that and assign creative text tasks to students to perform them in the classroom. The fact that only about one-third of the teachers are satisfied with the outcomes of their students' creative texts, raises doubts about the following abilities of teachers themselves: to prepare for a text creation lesson himself/herself, to assign preparation tasks to students, to structure the lesson/process of text creation, etc.
\end{abstract}

Keywords: primary students, primary teachers, text creation, lesson of mother tongue education.

\section{Introduction}

Based on research (cit. Creativity Development in Children at Home, at School and in Extracurricular Activities, 2014), both according to society's attitude towards creativity and the results of creativity, Lithuania's situation is one of the poorest in the EU, and the progress is not sufficient. In Lithuania, the share of creative employees is one of the lowest in the EU and the share of employees who are considered non-creative is much higher than the average of the EU. There may be various causes of the gap in creativity and limited progress, among which one of the main causes 
is insufficiently used possibilities while developing children's creativity at school (Ibid, p. 16).

In the process of mother tongue education, the creative tasks of a spoken and written text are focused on creativity development in children to the greatest extent.

According to the PIRLS (Progress in International Reading Literacy Study) report of 2016, the general reading achievement of the fourth-graders of Lithuanian general education schools has evidently increased eliminating the decline that formed between 2001 and 2011. Meanwhile, the situation of writing (text creation) remains a problematic area of education. In the reports of the national research of students' achievements (Subject Report of the National Research of Students' Achievements of 2014; Subject Report of the National Examination of Students' Achievements of 2017; Subject Report of the National Examination of Students' Achievements of 2018), the decreasing tendency of text creation of our primary graders is emphasized. Moreover, in the Subject Report of the National Examination of Students' Achievements of 2018, it was pointed out that since 2017 the results of the eighth-graders' writing test have significantly decreased as well. It is possible to presuppose that text creation skills insufficiently developed in primary grades cause difficulties in senior grades as well. Such a presupposition would be confirmed by the insights of the scientists of other countries (Genlotta, Grönlund, 2013) about the importance of the development of literacy skills: if children do not develop writing skills in their early years, later they will face bigger difficulties when they have to create longer and more complicated texts. It presupposes the problem question of the research - how is writing (text creation) development of primary students organized at their mother tongue lessons?

Having in mind that primary teachers are educators, on whom children's further learning and their success in future depend to a great extent alongside with the development of creative skills, the aim of the research is to evaluate the attitude of the primary teachers of the town X of Lithuania towards writing (text creation) development of students at their mother tongue lessons. The research intended to find out: 1) how teachers evaluate the conditions given by the curriculum of mother tongue education to develop students' creative abilities and to form text creation skills; 2) how text creation activities are organized; 3 ) what teachers' attitude towards students' abilities to perform creative text tasks is.

Methods of the research: scientific literature analysis, questionnaire survey, descriptive statistics.

Sample and procedure of the research. The research on teachers' attitude towards writing (text creation) development of students at their mother tongue lessons presented in the article is one of the parts of 
the research "Assessment of Creativity of Primary Teachers of the Town X" conducted in the academic year of 2018-2019.

According to the data of the department of education of the town $\mathrm{X}$, a total of 234 teachers work in the schools of the town $\mathrm{X}$ that deliver the primary education curriculum for the academic year 2018-2019. The permission to conduct the research was individually requested from the administration of each school presenting them the problem context of the research, the aim and objectives of the research, and defining the principles of research ethics - goodwill, respect for the person's dignity, justice, and the right to receive precise information. After the permission from the school administration was received, the potential research participants were given paper questionnaires, which they could fill in individually, at a convenient time for them, without the participation of the researchers, having agreed on the date of their return.

In the schools that agreed to participate in the research, a total of 167 questionnaires were handed out. 138 primary teachers filled in the questionnaires. Nine questionnaires that were filled in partially or not following the instruction were not analysed. Consequently, in the research report the generalized data of 129 questionnaires have been presented.

The demographic data of the research participants in fact reflect the situation of teachers working in the Lithuanian general education schools from the aspect of gender, age, and qualification. All the participants of the research are women ${ }^{1}$. The largest group was aged between 51 and 60 years (44\%) and the smallest group was drawn from 60 and more yearolds $(14 \%)^{2}$. Primary teachers with a high qualification ${ }^{3}$ work in primary grades of the town X: out of 129 teachers who participated in the research $75(58 \%)$ have acquired the qualification of a teacher methodologist, one teacher has acquired the qualification of a teacher expert. According to the work experience in primary grades, the biggest group of the research participants consisted of teachers, who have been working for 26-35 years (37\%), the smallest group consisted of teachers, who have been working for the first five years $(8 \%)$.

${ }^{1}$ In Lithuania the share of men who work in primary grades is only 5,5\% (Lietuva. Švietimas šalyje ir regionuose 2017. Mokytojas [Lithuania. Education in the Country and Regions 2017. Teacher], 2017, 25).

2 Approximately a half of teachers who work in general education schools of Lithuania are 50 years old and over: teachers under 30 years of age make up 3\%, 30-49 years old $-45 \%, 50-59$ years old $-39 \%$, 60 years old and over $-13 \%$ (Ibid, 25).

${ }^{3}$ In Lithuania teachers who have the qualification category of a methodologist or an expert are considered teachers with a high qualification. In 2016 there were $36,4 \%$ of teachers with such a qualification in Lithuania (Ibid, 26). 
Instrument of the research. The questionnaire of the teachers' attitude towards writing (text creation) development of students at their mother tongue lessons consisted of 19 statements that permit to identify how teachers evaluate the conditions given by the curriculum of mother tongue education to develop students' creative abilities; how text creation activities are organized; how teachers evaluate their abilities to establish favourable conditions for the formation and development of students' writing (text creation) abilities. Every statement was evaluated using a five-point scale from "strongly disagree" to "strongly agree." The overall indicator of each scale is obtained summing up all the scores of the respective scale. The internal consistency (Cronbach's Alpha) of the questionnaire of the teachers' attitude towards writing (text creation) development of students at their mother tongue lessons is 0,840 .

\section{Results}

According to the Lithuanian language curriculum for primary education (2016), primary students should learn various strategies of the creation of a fictional text based on the elements of re-creation (reproductive creativity) and original creativity, i.e., 1) to create a story based on one's personal experience and an imaginary one: according to the series of pictures; according to the given beginning and end; independently changing and remaking the plan given by the teacher; according to the guidelines of the story; according to the example of the literary work they have read; according to a self-made plan; 2) to write a retelling using questions, outline, chain of actions; 3) to write a description of an object/event/ phenomenon.

Retellings are probably the most reproductive tasks. During the Soviet times, various types of retellings (detailed, concise and selective) at the lessons of mother tongue education were one of the most frequent types of written assignments. In modern language teaching methodology, when particular attention is focused on the creative expression of the student himself/herself, the importance of retellings has evidently decreased (it can be noticed from the data of the picture 1 as well - only slightly more than a half of the research participants (64\%) strongly agree / agree with the statement that their students write retellings). Nevertheless, we tend to think that this type of text tasks should not be underestimated - poor retelling skills especially manifest themselves in senior grades when writing essays, preparing independent written assignments, presentations, etc. It means that: 1) when it is necessary to shorten the text written by others or its fragment, good skills of concise retelling are obligatory; 2) when it is important to emphasize important things, good skills of selective retelling 
are obligatory, 3) when it is necessary to present the content of the excerpt of the text, good skills of detailed retelling are obligatory. Moreover, every student combining intuitive and conscious understanding of a text must acquire knowledge and practical skills necessary to meet the motivation for self-expression, to create his/her own text. Having in mind that imitation is a psychological basis for learning a language, referring to the thoughts of one of the most famous specialists of the Lithuanian didactics Šoblinskas (1987), it is possible to give the following definition of the didactic importance of retelling: retelling requires to be able to think logically, to retain the consistency of the story, to distinguish between more important and secondary things; by going deep into the content and structure of a text written by others, a student learns practical linguistic activity, strengthens his/her own text creation skills; gets accustomed to using words and their forms not only correctly but also stylistically precisely; learns the ways of rendering thoughts - narration, description, reasoning; when writing retellings students more rapidly and to a greater extent feel the stylistic specifics of particular genres.

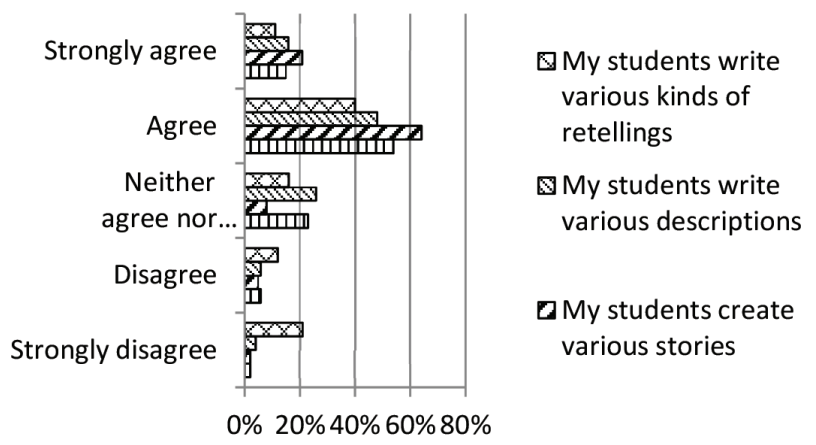

Figure 1. Distribution of the teachers' opinion about the text creation strategies they use $(\mathrm{n}=129)$

As the results of the present research show, one of the most frequent strategies used at the mother tongue lessons in primary grades is a story $85 \%$ of the primary teachers agree / strongly agree that they assign this type of writing tasks to students (see Figure 1). Slightly smaller shares of the respondents strongly agree / agree (69\%), that their students create fairy tales. From the linguistic point of view, a fairy tale is one of the types of narration with a trinomial (the beginning, the process and the climactic moment, and the end of the event) structure characteristic of it. Nevertheless, in comparison with a story, a fairy tale is a much more complex type of narration characterized by various levels of 
the relation between fantasy and reality, specific elements of composition. In pedagogical and psychological literature, the importance of fairy tales created by the child is especially emphasized: creating a fairy tale and, most importantly, writing it is one of the most valuable ways of creative self-expression. Nevertheless, the results of this part of the research provoke ambiguous thoughts. Referring to the findings of the Report of the National Research of Students' Achievements of 2014, for our fourthgraders it is the most difficult to create a fairy tale. The results of the scientific research (Bražienè, 2004; 2018) also show that the plots of the fairytale texts created by primary students are very poor - primitive, without the development of the action, in the fairy tales created by students the aims, wishes, behaviour motivation of the main character are not always clearly understood, the causal relations of the characters' actions are not understandable, the narration of events lacks consistency and completeness, there is a lack of imagination, the reproductive creative resources to create fairy tales are predominant; the majority of the fairy tales created by the third and fourth graders meet only the most minimum criteria, referring to which foreign scientists (Applebee, 1989; Pitcher, Prelinger, 1963; Preece, 1987) among other types of narration distinguish fairy tales created by five-year-old children. Consequently, this context suggests the idea about the organization of creative writing activities in general - how much time is given for creative text tasks, how the students are prepared to perform them and where they perform them, what motivation to create texts students have and what teachers' opinion about the final outcome of the student's creative writing is.

In Saylik's $(2014,20)$ words, "creative writing skills of primary school pupils are a physical and mental capacity to create an original, detailed, flexible and fluent creative written text. The concept of creative writing skills is a complex theoretical construct, which implicates in itself pupils' abilities: to characterise the essence of a creative written text by creating an appropriate title (originality), to create the content of a creative written text and reveal its topic (elaboration), to create a structured creative written text (fluency), to create an expressive, logical, integral and consistent creative written text (flexibility)".

In the Lithuanian language curriculum for primary education (2016, 27), it is emphasized that creative writing should be treated as an activity enabling to creatively express oneself while creating a meaningful, interesting written text, to share thoughts, feelings, opinion with others. In this document, the guidelines of the development of writing as a field of linguistic activity are outlined. It should be noted that the General Teaching Plan for the Primary Education Curriculum (2017) permits teachers to decide how to organize the educational process and model the contents 
of education striving for the aims of the primary education curriculum; it is possible to choose various ways of the integration of the contents of education, etc., i.e., teachers are given freedom to creatively plan and organize the educational process.

As it can be seen from the Figure 2, in the opinion of the majority of the teachers, who participated in the research, the curriculum of the Lithuanian language gives enough space for the development of students' creative abilities. Nevertheless, only almost one-third (26\%) of the teachers, who participated in the research, strongly agree / agree with the statement that working according to the curriculum of the Lithuanian language during the lessons there is enough time for creative writing (disagree / strongly disagree - 39\%). These numbers are illustrated by the teachers' comments, e.g.: Sometimes teachers are afraid not to fit into the time of the lesson. We are glad that in our school there are no bells, and, in case of inspiration, we can work longer; Teaching grammar takes a lot of time, children do not memorize spelling and punctuation rules in any way. And let us not forget teaching reading skills. There is simply no time left for creative works in these 45 minutes of the lesson; Creative writing works take time, and where should we get it from?; (...) I would like to give more examples, creative thoughts, but the scope of the curriculum of the Lithuanian language is very large. We have to "run gallop"; There is not enough time to perform creative tasks because the scope and curriculum of the Lithuanian language are very broad; The lesson is too short, therefore, the possibilities for creation are limited.

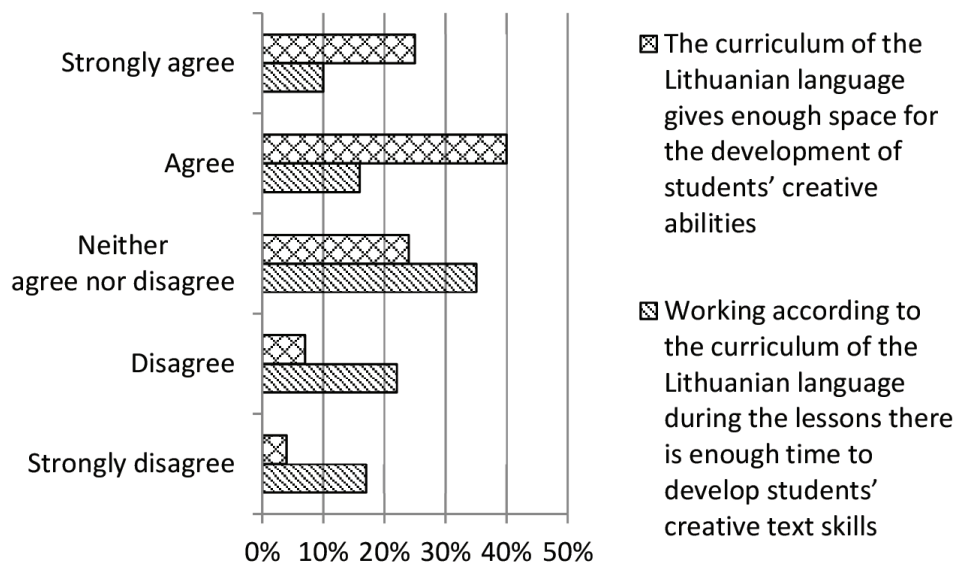

Figure 2. Evaluation of the curriculum of the Lithuanian language from the aspect of the development of creativity in students: distribution of the teachers' opinion $(n=129)$ 
In this context, it could be pointed out that a bigger share $(54 \%)$ of the research participants are over 50 years old. Consequently, they learned at school and the majority of them studied the didactics of mother tongue during the Soviet times, when the process of the development of the Lithuanian language was divided into separate fields, and at the same time into separate lessons - reading, learning grammar, and coherent language. Although in fact all the participants of the research are firmly convinced that they have enough didactic knowledge to teach students various text creation strategies, we tend to think that the experience of previous times, didactic knowledge and skills learned and established through many years of practical experience do not permit senior teachers to refocus on the system of mother tongue teaching/learning renewed after the restoration of independence, i. e., in the process of mother tongue education to integrate all the fields of linguistic activity listening (understanding of a spoken text), speaking (production of a spoken text, expressing thoughts verbally), reading (reading techniques, understanding and using of the text that is read), and writing (writing techniques, production of a written text). Therefore, in the integrated lesson of the Lithuanian language, when the subjects of the knowledge of the language structure, reading techniques, understanding literature, writing and creativity training need to be combined, the teacher faces problems in the consistent and purposeful development of students' text creation skills.

According to Daffern and Mackenzie (2015, 24), "specific writing elements require systematic consideration in the teaching and learning of writing, including text structure, sentence and grammatical structure, vocabulary, spelling, punctuation, and handwriting or word processing". Creative writing is a thinking process that requires quite big intellectual efforts from the child. In order to perform a text creation task well, it is important for the student to have enough time to consider the stages of the creative process / to make a plan of the essay, to work out the ideas, to coherently, logically, precisely, and correctly write his/her thoughts, to discuss the text with the teacher/peers, then to improve, correct, and present it. Referring to the recommendations of the scientists (Calkins, Ehrenworth, 2016), the ideal writing workshop includes ten minutes of explicit instruction, at least half an hour of writing time, ending with 5-10 minutes of sharing and goal setting with a peer. Nevertheless, only slightly more than a half (59\%) of the research participants strongly agree / agree with the statement that at least once a week they give a lesson to form creative text skills and prepare students for creative text work - they give a whole lesson on that (57\%) (see Figure 3). 


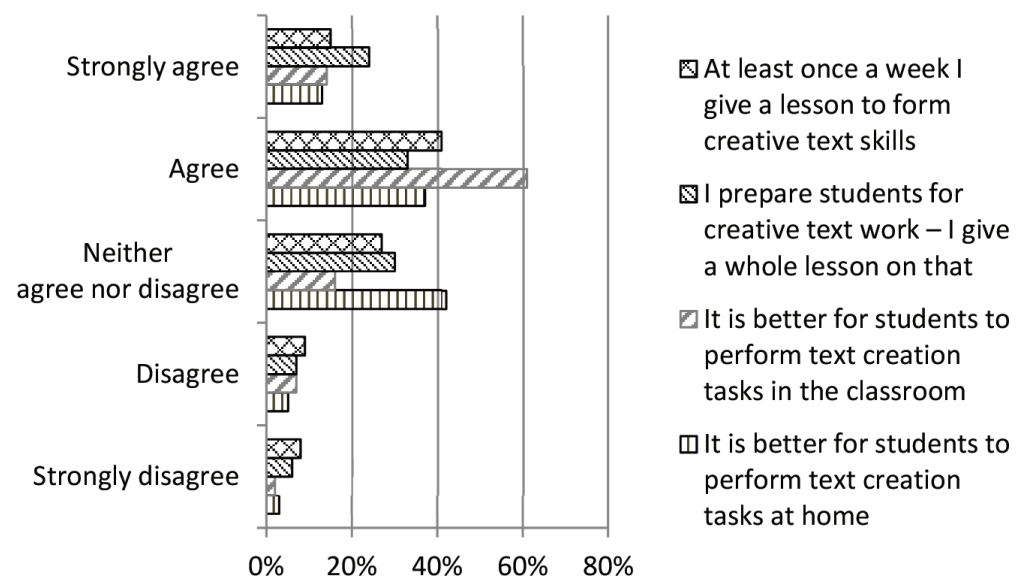

Figure 3. Distribution of the teachers' opinion about the time given for creative writing $(\mathrm{n}=129)$

Moreover, in this context, it is important to point out that in the General Teaching Plan for the Primary Education Curriculum for the academic year 2017-2018 and 2018-2019, the number of teaching hours for mother tongue education per week is quite big: 1 grade -8 hours, 2-4 grades 7 hours. Consequently, it is likely that the teacher when planning the lessons of mother tongue education could give a separate lesson for the formation of students' creative writing skills. This would not violate the integration of the fields of linguistic activity because in the creative writing lesson, listening, speaking, reading, and writing are inevitable.

As it can be seen from the picture 3, the teachers' opinion about where it is better for students to perform creative text tasks is twofold: some of them are convinced (strongly agree / agree - 50\%) that it should be in the classroom, the others think (strongly agree / agree - 54\%) that it should be at home. The scientists from other countries (Shook et al, 1989; Ritlyová, 2014) also notice that teachers ignore creative text tasks and usually assign them for homework. It must be mentioned that students have to be taught how to write: students must know how good they are at using theoretical knowledge in practice, i. e., whether they suitably create a text of one or another style, whether they consistently express thoughts, choose correct words, spell them correctly, etc. Another important element in the creative process is to encourage students to cooperate: to discuss about creative ideas, plans of writing, and revise students' work. If students have an audience who would listen to their writing, their motivation rises (Ritlyová, 2014). Therefore, it is possible to presuppose that when creative writing tasks are given for homework, the risk increases that the students 
will face writing difficulties. When the students cannot cope with these difficulties, their activeness decreases and this may provoke the motives forming a negative attitude towards writing a creative text.

There are very few researches in Lithuania conducted more than a decade ago that would evaluate primary students' disposition to create (Schoroškienè, 2000; Jasinskienè, Ramaneckienè, 2004; Schoroškienè, Marcinkevičiūtè, 2008). It has been noticed that only a third of first and second graders have a disposition to create. Although third and fourth graders' creative dispositions are more distinct, however, a strong negative attitude towards creative text tasks remains. It is possible to state that it corresponds to the findings of the scientists from other countries: referring to Grainger et al (2005), the children aged 7-9 years expressed predominantly negative attitudes to writing, typically describing it as boring, whilst a small, but worrying proportion of those aged 9-11 reflected an indifferent, somewhat detached disposition. As the results of the present research show, $42 \%$ of the respondents strongly agree / agree that primary students like creative writing tasks (neither agree nor disagree - 43\%, disagree / strongly disagree - 15\%). By analogy - only about one-third of the teachers are satisfied with the outcomes of their students' creative texts (strongly agree / agree $-36 \%$, neither agree nor disagree $-45 \%$, disagree / strongly disagree - 19\%) (see Figure 4).

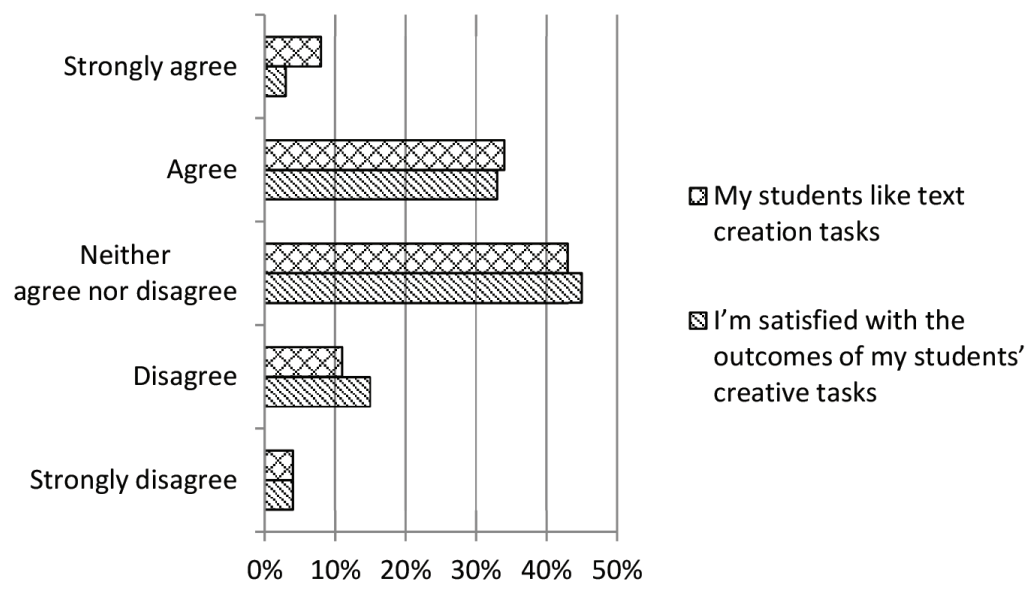

Figure 4. Expression of the teachers' opinion about the process of students' text creation and evaluation of outcomes $(n=129)$

The results of this part of the research raise doubts about the following abilities of teachers themselves: to prepare for a text creation lesson himself/herself, to assign preparation tasks to students, to structure 
the lesson/process of text creation, etc. Consequently, here attention is shifting towards the previously conducted research on the evaluation of teachers' creativity during the lessons of other subjects, in the conclusions of which it is stated that teachers lack competences related to the development of children's creativity: teachers plan their own activity during the lessons well but not the students' activity, its meaning and future outcomes; the main agent in the lesson is not the student but the teacher, who only partially properly chooses teaching/learning methods, poorly motivates students, does not establish conditions for students' initiative and creativity to unfold (according to Creativity Development in Children at Home, at School and in Extracurricular Activities, 2014).

\section{Conclusions}

According to the primary teachers, who participated in the research, their students learn various strategies of the creation of a fictional text based on the elements of re-creation (reproductive creativity) and original creativity. Most often primary students learn to create a story, least often they learn to write a retelling.

The development of primary students' writing (text creation) skills should be a process of teaching/learning how to write, which is very well thought over by the teacher and which is consistently and purposefully organized. Nevertheless, referring to the data of the research, primary teachers working according to the curriculum of mother tongue education do not have enough time for the formation of students' text creation skills. We tend to consider the lack of time emphasized by the teachers as the possible lack of the didactic competences of the teachers themselves to work according to the system of mother tongue teaching/learning renewed after the restoration of independence and use the freedom to creatively plan and organize the educational process.

During the lessons of creative text writing, students must be taught how to write, must be encouraged to collaborate; they must be provided immediate help when they face writing difficulties. However, as it can be seen from the results of the research, only slightly more than a half of the teachers at least once a week give a lesson to form students' creative text skills and prepare students to create a text - they give a whole lesson on that and assign creative text tasks to students to perform them in the classroom.

It would be possible to state that the majority of teachers understand that the success of the performance of creative text tasks depends both on the teacher and the student. However, the fact that even less than a half of the research participants admit that their students like creative writing tasks 
and only about one-third of the teachers are satisfied with the outcomes of their students' creative texts, raises doubts about the following abilities of teachers themselves: to prepare for a text creation lesson himself/herself, to assign preparation tasks to students, to structure the lesson/process of text creation, etc.

The presented results of the quantitative research only partially inform how the primary teachers of the town $\mathrm{X}$ of Lithuania organize the development of primary students' writing (text creation) at their mother tongue lessons. The results of the present research presupposed the perspective of our further qualitative research, i.e., to find out: 1) how the teacher prepares for a text creation lesson himself/herself, how he/she assigns preparation tasks to students and what kind of tasks it is, how he/ she structures the lesson/process of text creation; 2) what students' opinion about text creation lessons is; in the students' opinion, what the necessary preconditions are for the formation of students' positive relation with creative text tasks and how teachers could enhance students' creative attitudes so that the outcomes of students' creative tasks could be better.

\section{References}

Applebee, A. N. (1989). The child's concept of story: ages two to seventeen. Chicago: University of Chicago Press.

Calkins, L., Ehrenworth, M. (2016). Growing extraordinary writers: Leadership decisions to raise the level of writing across a school and a District. The Reading Teacher, 70(1), 7-18. DOI: 10.1002/trtr.1499.

Bražienè, N. (2004). The Development of Creativity of Primary School Pupils by Fairy-Tales: Summary of the Doctoral Dissertation. Siauliai University.

Bražienè, N. (2018). Pasakiškasis 8-11 metų vaikų kuriamų tekstų pasaulis. [In Lithuanian. Fairy World of the Texts Created by 8-11 Year Old Children.] In Juodaitytè, A. ir kt. (2018). Šiuolaikinè vaikystè ir vaiku ugdymas: socialiniai-kultūriniai kontekstai: Mokslo studija. [In Lithuanian. Contemporary childhood and education of children: social-cultural contexts: Study]. Šiaulių universitetas. P. 137-186.

Daffern, T., Mackenzie, N. (2015). Building strong writers: Creating a balance between the authorial and secretarial elements of writing. Literacy Learning: the Middle Years, 23(1), 23-32. Access to Document: < http://www.academia.edu/download/39261249/ Daffern_Mackenzieafter_TDNM_Final.pdf $>$.

Genlotta, A. A., Grönlund, Å. (2013). Improving literacy skills through learning reading by writing: The iWTR method presented and tested. Computers \& Education, 67, 98-104. DOI: 10.1016/j.compedu.2013.03.007.

Grainger, T., Goouch, K., Lambirth, A. (2005). Creativity and Writing: Developing Voice and Verve in the Classroom. London \& New York: Routledge.

Jasinskienė, J., Ramaneckienè, I. (2004). Ketvirtokų sampratos apie galimybes patiems dalyvauti kūrybiniame procese tyrimas [In Lithuanian. Research on fourth-formers' opportunities to participate in creative processes]. Jaunujų mokslininku darbai, 3, 49-58. 
Lietuva. Švietimas šalyje ir regionuose 2017. Mokytojas. (2017). [In Lithuanian. Lithuania. Education in the Country and Regions 2017. Teacher]. Vilnius: ŠMM. Access to Document: $<$ https://www.smm.lt/uploads/documents/kiti/Svietimas\%20regionuose\%202017. pdf $>$.

Lietuviu kalbos pradinio ugdymo bendroji programa. [In Lithuanian. Lithuanian language curriculum for primary education]. (2016). Vilnius: ŠMM.

Pitcher, E. G., Prelinger, E. (1963). Children tell stories: An analysis of fantasy. New York: International Universities Press.

Preece, A. (1987). The range of narrative forms conversationally produced by young children. Journal of child language, 14(2). Cambridge University Press, 353-373.

Ritlyová, A. (2014). Creative Use of Literature in Language Teaching. Tvorivost’ v škole škola tvorivosti: Online Konferencia (29.-30. 10. 2014). Access to Document: < https:// www.pulib.sk/web/kniznica/elpub/dokument/Germuskova2/subor/Ritlyova.pdf > .

$2014 \mathrm{~m}$. nacionalinio mokiniu pasiekimy tyrimo dalykine ataskaita [In Lithuanian. Subject Report of the National Research of Students' Achievements of 2014]. Vilnius: NMPT. Access to Document: < https://www.nec.lt/failai/5837_NT2014_Dalykine_ataskaita.pdf > .

2017-2018 ir 2018-2019 m. m. Pradinio ugdymo programos bendrasis ugdymo planas [In Lithuanian. The General Teaching Plan for the Primary Education Curriculum]. (2017). Vilnius: ŠMM.

2017 metu nacionalinio mokiniu pasiekimu patikrinimo ataskaita [Subject Report of the National Examination of Students' Achievements of 2017]. (2017). Vilnius: NEC. Access to Document: < https://www.nec.lt/failai/7303_NMPP-2017-ATASKAITA.pdf > .

2018 mety nacionalinio mokiniu pasiekimu patikrinimo ataskaita [In Lithuanian. Subject Report of the National Examination of Students' Achievements of 2018]. (2018). Vilnius: NEC. Access to Document: < https://www.nec.lt/failai/7877_NMPP_2018_ATASKAITA. pdf $>$.

Saylik, A. (2014). The development of creative writing skills of primary school pupils using interactive whiteboard: Summary of the Doctoral Dissertation. Lithuanian University of Educational Sciences.

Shook, S. E., Marrion, L. V., Ollila, L. O. (1989). Primary Children's Concepts About Writing. The Journal of Educational Research, 82(3),133-139. DOI: 10.1080/00220671.1989.10885882.

Schoroškienè, V. (2000). Pirmosios ir antrosios klasės mokinių kūrybinès nuostatos. [In Lithuanian. Creative approaches of the first and second form pupils. Pedagogika, 43. P. 117-124.

Schoroškienè, V., Marcinkevičiūtè, I. (2008).Trečios ir ketvirtos klasės mokinių kūrybinès nuostatos [In Lithuaninan. Creative Attitudes of 3rd and $4^{\text {th }}$ Formers]. Pedagogika, 90, 129-135.

Šoblinskas, A. (1987). Lietuvių kalbos didaktika. Vilnius: Mokslas.

Tarptautinis skaitymo gebejimu tyrimas [Progress in International Reading Literacy Study] PIRLS 2016: Ataskaita 4 klasè. (2017). Vilnius: NEC. Access to Document: < https:// www.nec.lt/failai/7237_PIRLS2016_Ataskaita.pdf > .

Vaiku kūrybiškumo ugdymas namuose, mokykloje ir popamokinëje veikloje: Teminio tyrimo ataskaita [In Lithuanian. Creativity Development in Children at Home, at School and in Extracurricular Activities]. (2014). Vilnius: LR Vyriausybės kanceliarija. 